\title{
Effects of convective ice evaporation on interannual variability of tropical tropopause layer water vapor
}

\author{
Hao Ye, Andrew E. Dessler, and Wandi Yu \\ Department of Atmospheric Sciences, Texas A\&M University, College Station, TX, USA \\ Correspondence: Andrew E. Dessler (adessler@tamu.edu)
}

Received: 12 October 2017 - Discussion started: 25 October 2017

Revised: 12 February 2018 - Accepted: 25 February 2018 - Published: 3 April 2018

\begin{abstract}
Water vapor interannual variability in the tropical tropopause layer (TTL) is investigated using satellite observations and model simulations. We break down the influences of the Brewer-Dobson circulation (BDC), the quasibiennial oscillation (QBO), and the tropospheric temperature $(\Delta T)$ on TTL water vapor as a function of latitude and longitude using a two-dimensional multivariate linear regression. This allows us to examine the spatial distribution of the impact of each process on TTL water vapor. In agreement with expectations, we find that the impacts from the BDC and QBO act on TTL water vapor by changing TTL temperature. For $\Delta T$, we find that TTL temperatures alone cannot explain the influence. We hypothesize a moistening role for the evaporation of convective ice from increased deep convection as the troposphere warms. Tests using a chemistryclimate model, the Goddard Earth Observing System Chemistry Climate Model (GEOSCCM), support this hypothesis.
\end{abstract}

\section{Introduction}

Stratospheric water vapor plays an important role in both the chemistry (Dvortsov and Solomon, 2001; Stenke and Grewe, 2005) and radiative energy budget (Forster and Shine, 1999; Solomon et al., 2010; Dessler et al., 2013) of the atmosphere. Air enters the stratosphere from the tropical troposphere mainly through the tropical tropopause layer (TTL, $\sim 15$ $18 \mathrm{~km}$ ) (Sherwood and Dessler, 2000; Fueglistaler et al., 2009), which serves as a transition region between the troposphere and stratosphere. It is generally recognized that the coldest temperatures in the TTL act like a "cold trap" that provides primary control on the amount of water vapor entering the lower stratosphere (Mote et al., 1996; Holton and Gettelman, 2001). Large interannual variations of TTL water vapor have been observed and attributed to a set of physical processes that affect water vapor by varying TTL temperatures, such as the quasi-biennial oscillation (QBO) (Geller et al., 2002; Fueglistaler and Haynes, 2005; Liang et al., 2011; Liess and Geller, 2012; Randel and Jensen, 2013; Wang et al., 2015; Tao et al., 2015) and the Brewer-Dobson circulation (BDC) (Randel et al., 2006; Calvo et al., 2010; Dessler et al., 2013, 2014; Fueglistaler et al., 2014; Gilford et al., 2016).

Another important process is the deep convection that reaches the TTL. Clouds comprised of convective ice can have important impacts on planetary energy balance (Lee et al., 2009; Zhou et al., 2014), and their evaporation can moisten the TTL (Corti et al., 2008; Wang and Dessler, 2012). The efficiency of cloud evaporation is strongly related to ambient relative humidity (Dessler and Sherwood, 2004; Wright et al., 2009) because high relative humidity inhibits evaporation. Recent aircraft measurements (Anderson et al., 2012; Herman et al., 2017) and satellite observations (Dessler and Sherwood, 2004; Schwartz et al., 2013; Sun and Huang, 2015) confirm that the deep convection enhances lower stratospheric water vapor over the North American summer monsoon region, where relative humidity is low.

In the tropics, the influence of convection on observed water vapor amounts is less clear. It seems certain that convective ice evaporation at least occasionally moistens the stratosphere (Khaykin et al., 2009; Hassim and Lane, 2010; Carminati et al., 2014; Frey et al., 2015; Virts and Houze, 2015), but the impact of convection there is muted because the relative humidity of the TTL is high, suppressing evaporation, and only convection reaching above the cold point is likely to significantly impact the humidity of the stratosphere (Dessler et al., 2007). 
Several modeling studies have addressed this by adding convection moistening into the trajectory model simulation, through a convective probability scheme (Dessler et al., 2007; Schoeberl and Dessler, 2011), a reanalysis-based anvil ice scheme (Schoeberl et al., 2014), or an observation-based convective cloud-top scheme (Ueyama et al., 2014, 2015). All of these are in agreement that the convective ice can moisten the TTL and lower stratosphere. Schoeberl et al. (2014) and Ueyama et al. (2015) estimated that convective ice evaporation increases TTL water vapor by 0.3 and 0.5 to 0.6 ppmv, respectively - about a $10-15 \%$ effect. In addition, a recent case study has shown that evaporation of convective ice could account for a significant part of the TTL water vapor response to the strong El Niño of 2015-2016 (Avery et al., 2017).

On longer timescales, the impact of ice evaporation on stratospheric water vapor could be much more important. Almost all climate models predict that the water vapor in the upper troposphere/lower stratosphere (UTLS) will increase over the next century (Gettelman et al., 2010), and a significant fraction of this increase was found to be due to the evaporation of convective ice from convection in two chemistryclimate models (Dessler et al., 2016). This gives us ample motivation to look more closely at the impact of convective ice evaporation on TTL water vapor in the observations.

The purpose of this study is to investigate in more detail the physical processes controlling the interannual variations of water vapor in the TTL, particularly the influence of evaporation of convective ice. Previous work has mostly taken a "forward model" approach - where a model (usually a dynamical model coupled to a microphysical model) driven by observations of winds, temperatures, and convection is used to make an explicit estimate of the convective influence. Our analysis takes a different approach - we use a statistical model to decompose observed water vapor variability into the dominant physical processes known to drive water vapor. We do this in both observations and water vapor simulated by a trajectory model. Because the trajectory model does not include convection, differences in the results will be tied to the influence of convection. We verify the methodology by reproducing it in a chemistry-climate model with known convection.

\section{Data and methods}

\subsection{Microwave Limb Sounder water vapor}

The observations of TTL water vapor are from the Earth Observing System (EOS) Aura Microwave Limb Sounder (MLS) (Lambert et al., 2007; Read et al., 2007). The MLS instrument has obtained continuous high-quality global observations of water vapor in the upper troposphere and stratosphere since August 2004. The data are available from https: //mls.jpl.nasa.gov/.
Here, we use MLS version 4.2 level-2 water vapor retrievals from August 2004 to December 2016. The daily water vapor mixing ratio measurements are binned and averaged to produce monthly data on a $4^{\circ} \times 8^{\circ}$ latitude and longitude grid with the quality control following the instruction in Livesey et al. (2017). We focus on the interannual anomalies of water vapor from $30^{\circ} \mathrm{N}$ to $30^{\circ} \mathrm{S}$ at $100 \mathrm{hPa}$. Throughout this paper, the interannual anomalies at each grid point are calculated by subtracting the average annual cycle at that grid point.

\subsection{GEOSCCM}

We also use simulations of TTL water vapor from the Goddard Earth Observing System Chemistry Climate Model (GEOSCCM) in this study. The state-of-the-art GEOSCCM includes the GEOS-5 atmospheric general circulation model (Molod et al., 2012) with a single-moment cloud microphysics scheme (Bacmeister et al., 2006; Barahona et al., 2014) and the StratChem stratospheric chemical mechanism (Pawson et al., 2008; Oman and Douglass, 2014). The GEOSCCM simulation provides long-term simulations of temperature, water vapor, horizontal winds, diabatic heating rates, and convective ice content with a resolution of $2^{\circ} \times 2.5^{\circ}$ in latitude and longitude on 72 vertical model levels, up to $0.01 \mathrm{hPa}$.

In this study, we investigate water vapor simulated by the GEOSCCM in the TTL during model years corresponding to the MLS period. As these simulations are from a free-running model, climate variability in the model is not synchronous with that in the observations, so the comparisons with MLS observations are done statistically - using regression models (discussed below).

\subsection{Trajectory model}

We also produce simulations of TTL water vapor using a domain-filling forward trajectory model, which has been used in previous work to reproduce water vapor, ozone, and carbon monoxide anomalies in the TTL and lower stratosphere (Schoeberl and Dessler, 2011; Schoeberl et al., 2012, 2013; Dessler et al., 2014; Wang et al., 2014).

This model uses Bowman's trajectory code (Bowman, 1993; Bowman and Carrie, 2002). The parcels are driven by 6-hourly horizontal winds and total diabatic heating rates from either reanalysis datasets or from the GEOSCCM. When comparing to MLS data, we use trajectory runs driven by two reanalysis datasets: the European Centre for MediumRange Weather Forecasts (ECMWF) ERA-Interim reanalysis (ERAi) (Dee et al., 2011) and NASA's Modern-Era Retrospective Analysis for Research and Applications version 2 (MERRA-2) (Bosilovich et al., 2016). When comparing to GEOSCCM output, we drive the trajectory model with meteorological fields from the GEOSCCM. 
In all simulations, 1350 parcels are released every day from January 2000 to December 2016 on an equal area grid from $60^{\circ} \mathrm{N}$ to $60^{\circ} \mathrm{S}$. The parcels are released on the $370 \mathrm{~K}$ isentropic level, which is above the zero net diabatic heating level over the tropics $(\sim 355-360 \mathrm{~K})$ but below the cold point $(\sim 375-380 \mathrm{~K})$. Each parcel travels forward following the horizontal winds and diabatic heating rate. Once a parcel has a pressure larger than $250 \mathrm{hPa}$, it is regarded as having descended back into the troposphere and is removed from the model.

Each parcel is initialized with a water vapor mixing ratio of 200 parts per million by volume (ppmv). Along the trajectory, a parcel will immediately be dehydrated to saturation once its water vapor mixing ratio exceeds a predetermined saturation threshold, which is $100 \%$ in this study. The saturated water vapor mixing ratio is obtained from the thermodynamic equation with respect to ice (Murphy and Koop, 2005) based on temperatures from reanalyses or the GEOSCCM. The production of water vapor from methane oxidation is also included in these trajectory model runs but it has very little effect on water vapor in the TTL (Dessler et al., 2014).

The water vapor mixing ratio from the trajectory model is gridded into $4^{\circ} \times 8^{\circ}$ bins, just as the MLS data were. In the vertical, the trajectory output is binned by averaging the parcels in a pressure range around each MLS or GEOSCCM level. When comparing to MLS, the gridded water vapor mixing ratio is then re-averaged using the MLS averaging kernels following the instruction from Livesey et al. (2017). When doing this kernel averaging, grid boxes with no trajectory parcels (mostly at low altitudes) are filled with monthly water vapor mixing ratios from the reanalyses (ERAi and MERRA-2). Sensitivity tests confirm that changing water vapor mixing ratio from the reanalyses has no impact on the spatial distribution of the anomalies of TTL water vapor that are the focus of this paper.

\subsection{Convection clouds}

We also use estimates of convective cloud occurrence produced by combining geostationary infrared satellite imagery and microwave rainfall measurements (Pfister et al., 2001; Bergman et al., 2012; Ueyama et al., 2014, 2015). The data have a horizontal resolution of $0.25^{\circ} \times 0.25^{\circ}$, a temporal resolution of $3 \mathrm{~h}$, and cover the period from 2005 to 2016. In this paper, we use the cloud-top height and cloud-top potential temperature to estimate the convective cloud occurrence frequency in the TTL, which we take to be an indicator of convective influence on the TTL. These data are available from https://bocachica.arc.nasa.gov/ lpfister/cloudtop/.

\section{Results}

\subsection{Influences of the BDC and QBO on TTL water vapor}

Figure 1 shows monthly and tropical averaged $100 \mathrm{hPa}$ water vapor anomalies from MLS observations and from trajectory model runs driven by meteorology from ERAi (traj_ERAi) and MERRA-2 (traj_MERRA2). Similar to the results in Dessler et al. $(2013,2014)$ at $82 \mathrm{hPa}$, there is good agreement between the observations and trajectory models at $100 \mathrm{hPa}$.

Dessler et al. $(2013,2014)$ also showed that we can fit tropical average anomalies of $82 \mathrm{hPa}$ water vapor with a simple linear model:

$\mathrm{H}_{2} \mathrm{O}=a \cdot \mathrm{BDC}+b \cdot \mathrm{QBO}+c \cdot \Delta T+r$,

where $\mathrm{BDC}, \mathrm{QBO}$, and $\Delta T$ are indices representing the strength of the Brewer-Dobson circulation, the phase of the QBO, and the tropospheric temperature anomalies of the tropical climate system, respectively. Smalley et al. (2017) verified that this approach is also valid in chemistry-climate models.

To gain additional physical insight into the regression result, in this paper, we perform a similar multivariable regression but at individual grid points in the TTL:

$$
\begin{aligned}
& \mathrm{H}_{2} \mathrm{O}\left(x_{i}, y_{j}\right)=a\left(x_{i}, y_{j}\right) \cdot \mathrm{BDC}+b\left(x_{i}, y_{j}\right) \cdot \mathrm{QBO} \\
& \quad+c\left(x_{i}, y_{j}\right) \cdot \Delta T+r\left(x_{i}, y_{j}\right) .
\end{aligned}
$$

Here, $\mathrm{H}_{2} \mathrm{O}\left(x_{i}, y_{j}\right)$ represents the $\mathrm{H}_{2} \mathrm{O}$ anomaly time series at $100 \mathrm{hPa}$ in a grid box centered at longitude $x_{i}$ and latitude $y_{j}$. The coefficients $a, b$, and $c$, as well as the residual term $r$, are also functions of latitude and longitude.

The regressors in Eq. (2) are the same tropical average time series used in Dessler et al. (2013, 2014): BDC is the Brewer-Dobson circulation index - here, we use the tropical averaged diabatic heating rate anomaly at $82 \mathrm{hPa}$, with units of $\mathrm{K} \mathrm{day}^{-1}$. QBO is a quasi-biennial oscillation index, and here we use the standardized monthly and zonally averaged equatorial zonal wind anomaly at $50 \mathrm{hPa}$, with units of $\mathrm{m} \mathrm{s}^{-1} . \Delta T$ is the tropical averaged tropospheric temperature anomaly at $500 \mathrm{hPa}$, with units of Kelvin. Because these regressors are tropical average values, they do not vary with location. The QBO index is lagged by 2 months in the regression because the phase of the QBO takes time to impact the TTL temperature and then the water vapor at $100 \mathrm{hPa}$ (Dessler et al., 2013). There is no lag for the BDC and $\Delta T$ indices in this study.

We first analyze MLS water vapor observations. We run the regression on these observations twice: once using BDC and $\Delta T$ regressors from the ERAi reanalysis and again using regressors from the MERRA-2 reanalysis. The QBO index is the same in both regressions (we use observations downloaded from http://www.cpc.ncep.noaa.gov/data/ indices/qbo.u50.index). 


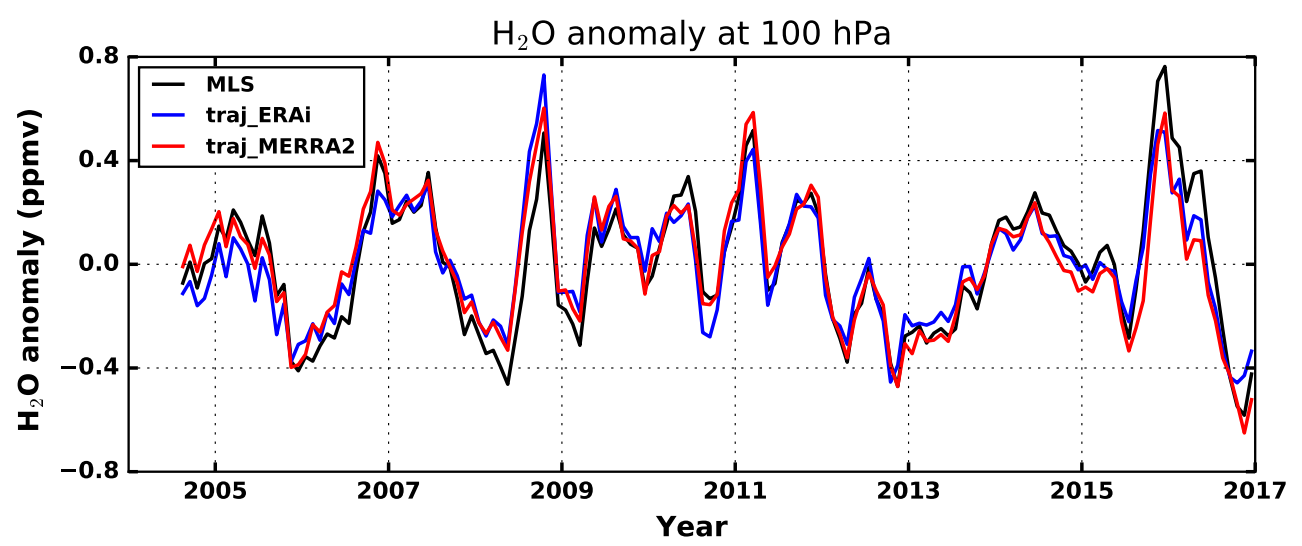

Figure 1. Tropical average $\left(30^{\circ} \mathrm{N}-30^{\circ} \mathrm{S}\right)$ monthly water vapor anomalies at $100 \mathrm{hPa}$ from MLS observations (black line) and from trajectory model runs driven by ERAi (blue line) and MERRA-2 (red line) from August 2004 through 2016. Anomalies are calculated by subtracting the mean annual cycle.

The BDC coefficients (Fig. 2a and d) are negative over the tropics, consistent with the idea that an enhanced BrewerDobson circulation cools the TTL (Yulaeva et al., 1994) and reduces water vapor (Randel et al., 2006; Dhomse et al., 2008). The QBO coefficients (Fig. 3a and d) are positive over almost all of the tropics, as the positive phase of QBO tends to decrease the upwelling in the TTL, thereby warming it (Plumb and Bell, 1982; Davis et al., 2013).

We also run the regression on water vapor simulated by the trajectory model. We use BDC and $\Delta T$ regressors from the same reanalysis used to drive each trajectory model (i.e., we use ERAi fields to regress the ERAi-driven trajectory model); the QBO index is always from the NCEP observations.

The BDC coefficients from regression of the trajectory models (Fig. 2b and e) agree well with the coefficients from the regressions of the MLS observations (Fig. 2a and d). The average BDC coefficient in the MLS/ERAi regression is -2.6 ppmv $\left(\mathrm{K} \mathrm{day}^{-1}\right)^{-1}$ (Fig. 2a), in good agreement with the average value from the accompanying trajectory regression, -2.4 ppmv $\left(\mathrm{K} \mathrm{day}^{-1}\right)^{-1}$ (Fig. 2b). The grid-point-bygrid-point scatter plot (Fig. 2c) demonstrates this agreement in more detail.

The average BDC coefficient in the MLS/MERRA-2 regression is $-2.3 \mathrm{ppmv}\left(\mathrm{K} \mathrm{day}^{-1}\right)^{-1}$ (Fig. 2d). The average coefficient from the accompanying trajectory regression is $-1.4 \mathrm{ppmv}\left(\mathrm{K} \mathrm{day}^{-1}\right)^{-1}$ (Fig. 2e). This larger difference stems from what appears to be problems in the MERRA-2 heating rates. These heating rates disagree significantly with those from both ERAi as well as the original MERRA. Thus, we put more weight on the ERAi results for this coefficient and conclude that the BDC response is well simulated by the trajectory model.

The QBO coefficients from the regressions of the trajectory models are shown in Fig. $3 \mathrm{~b}$ and e; grid-pointby-grid-point scatter plots are shown in Fig. 3c and f. For the MLS/ERAi comparison (Fig. 3c), the aver- age QBO coefficients are $0.084 \mathrm{ppmv}\left(\mathrm{ms}^{-1}\right)^{-1}$ for the MLS and $0.075 \mathrm{ppmv}\left(\mathrm{m} \mathrm{s}^{-1}\right)^{-1}$ for the trajectory model; for the MLS/MERRA2 comparison (Fig. 3f), the average coefficients are $0.14 \mathrm{ppmv}\left(\mathrm{ms}^{-1}\right)^{-1}$ for the MLS and $0.15 \mathrm{ppmv}\left(\mathrm{m} \mathrm{s}^{-1}\right)^{-1}$ for the trajectory model. As with the BDC comparison, we conclude that the trajectory model does a good job reproducing the regressions of the MLS data.

Overall, the trajectory model accurately captures the impact of the BDC and QBO on TTL water vapor for both the tropical average and the spatial distribution. This supports the hypothesis that these processes mainly influence TTL water vapor by varying large-scale TTL temperatures and transport (Giorgetta and Bengtsson, 1999; Randel et al., 2000, 2006; Geller et al., 2002; Dhomse et al., 2008; Liang et al., 2011; Davis et al., 2013; Dessler et al., 2013, 2014; Wang et al., 2015), which we expect the trajectory model to reproduce. For this reason, we will not focus any further on these coefficients.

\subsection{Influence of tropospheric temperature on TTL water vapor}

Coefficients of $\Delta T$ from the MLS regressions are mostly positive, with large increases over the tropical warm pool region (TWP) and Indian Ocean (Fig. 4a and d), indicating that warming of the tropical troposphere increases TTL water vapor mixing ratio there. Over the central equatorial Pacific (CEP), however, a warming troposphere decreases TTL water vapor.

The decrease in TTL water vapor in the CEP is not entirely unexpected. TTL temperatures are usually coldest - and water vapor a minimum - above the convection maximum in the TWP. As $\Delta T$ increases in response to an El Niño event, this convective maximum, and its associated TTL cold pool, shifts eastward from the TWP to the CEP (corresponding to the shift from Fig. 5a to b) (Davis et al., 2013; Hu et al., 2016; Konopka et al., 2016; Avery et al., 2017). Changes in 
BDC coefficients [ppmv/(K day $\left.\left.{ }^{-1}\right)\right]$

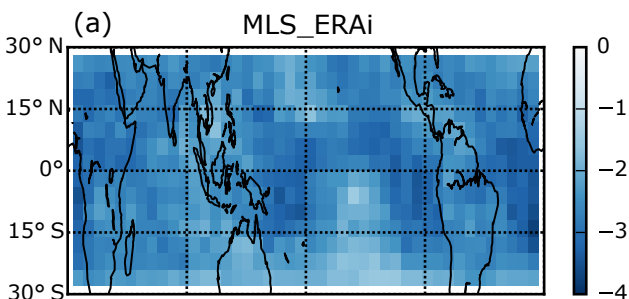

(d) MLS_MER2
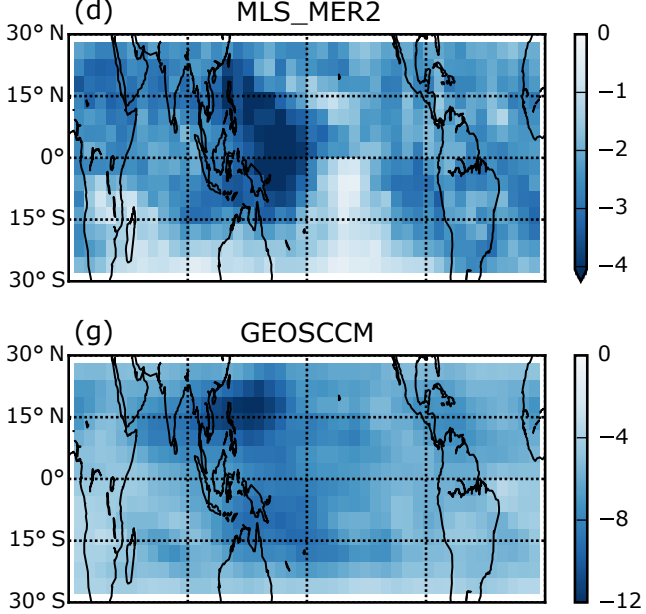

(b)

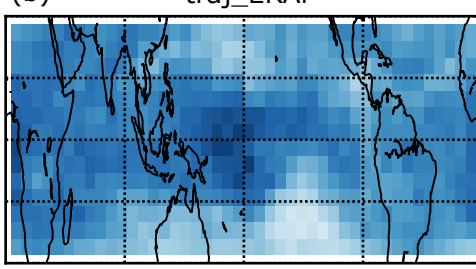

(e)

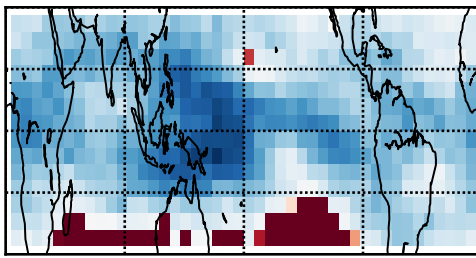

(h)

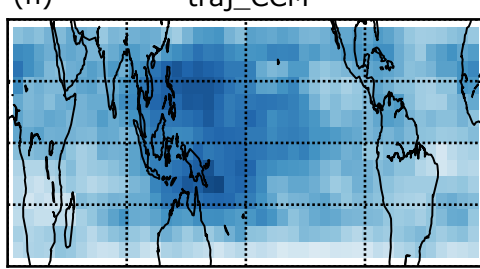

(j)

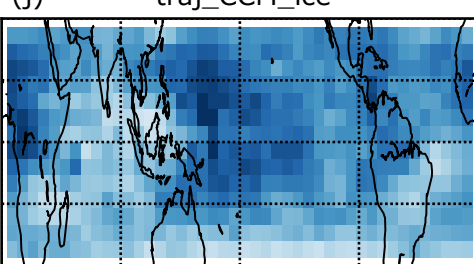

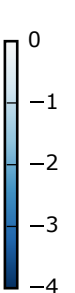

(c) MLS_ERAi

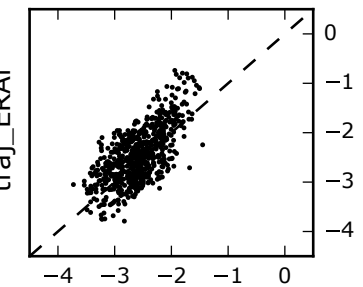

(f) MLS_MER2
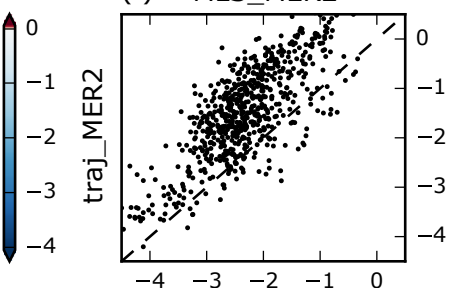

(i) GEOSCCM
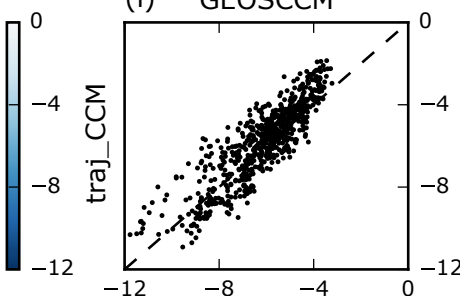

(k) GEOSCCM

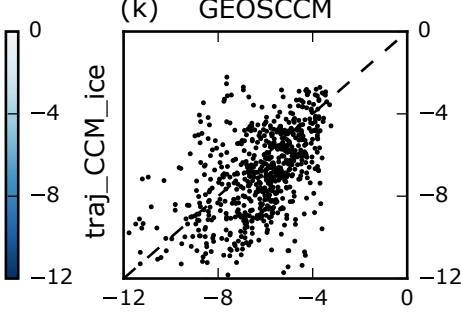

Figure 2. Coefficients of the BDC regressor from MLS and GEOSCCM water vapor fields (a, d, $\mathbf{g})$, as well as the coefficients from regression of the associated trajectory model fields $(\mathbf{b}, \mathbf{e}, \mathbf{h}, \mathbf{j})$. Scatter plots of MLS/GEOSCCM regressions vs. trajectory model regressions indicate the similarity of the fields (c, f, i, k). The MLS and associated trajectory model regressions cover the period August 2004 to December 2016 between $30^{\circ} \mathrm{N}$ and $30^{\circ} \mathrm{S}$. The GEOSCCM and associated trajectory model regressions cover the model years 2005-2016. The bottom row shows coefficients from regressions of a run of the trajectory model driven by GEOSCCM meteorology that includes evaporation of convective ice.

TTL water vapor are expected to mirror this, with increases in water vapor in the TWP and decreases in the CEP as $\Delta T$ increases.

Both the MLS and trajectory model regressions show this dipole pattern. However, the MLS regressions yield $\Delta T$ coefficients that are systematically higher than those found in the trajectory model regressions throughout the tropics (Fig. 4c and f). For the MLS/ERAi comparison (Fig. 4c), the average coefficients are $0.43 \mathrm{ppmv} \mathrm{K}^{-1}$ for the MLS and $0.28 \mathrm{ppmv} \mathrm{K}^{-1}$ for the trajectory model; for the MLS/MERRA-2 comparison (Fig. 4f), the average coefficients are $0.20 \mathrm{ppmv} \mathrm{K}^{-1}$ for the MLS and $0.05 \mathrm{ppmv} \mathrm{K}^{-1}$ for the trajectory model. We have also done regressions us- ing tropical average values (using Eq. 1, similar to what was done in Dessler et al. $(2013,2014))$ and find that the $\Delta T$ coefficients from MLS and trajectory models are statistically different with probabilities of 85 and $70 \%$ for ERAi and MERRA-2, respectively.

We hypothesize that the evaporation of convective ice accounts for the difference between the $\Delta T$ coefficients in the MLS and trajectory model regressions. As convection moves eastward during an El Niño event, there is an accompanying increase in convective ice in the TTL (as seen in Fig. 5a and b; see also Avery et al., 2017), where it evaporates and hydrates the TTL. The moistening from evaporation spreads throughout the tropics and increases the water vapor every- 


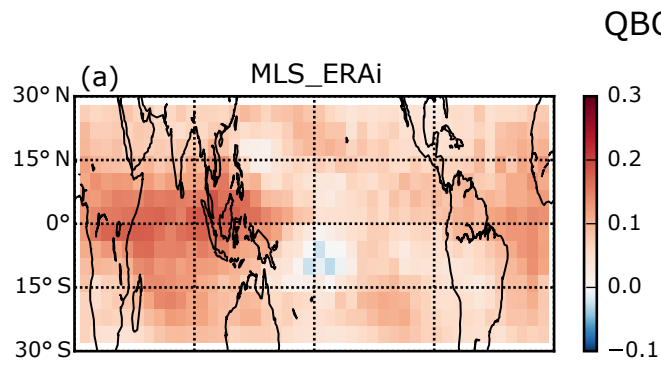

QBO coefficients [ppmv/(m s-1)]

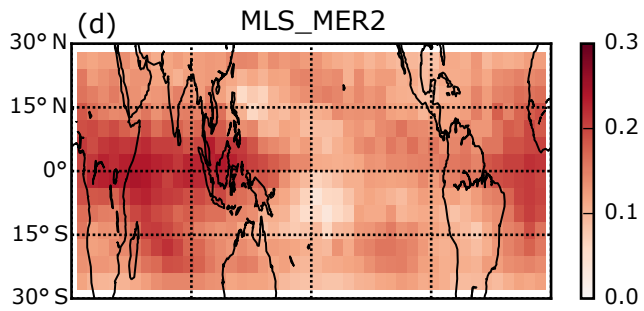

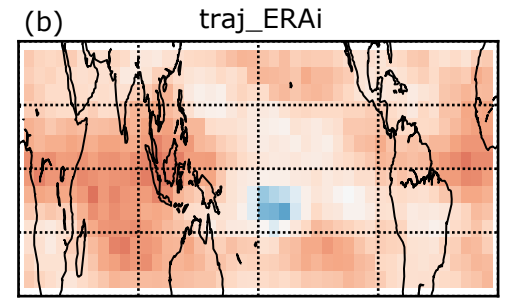

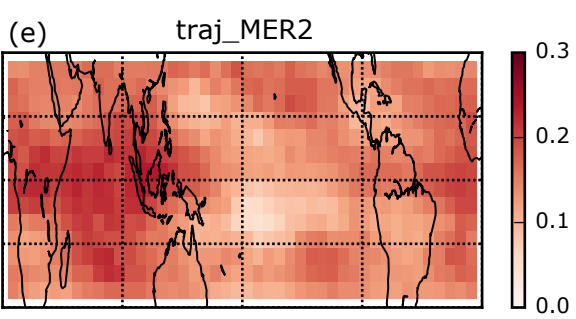

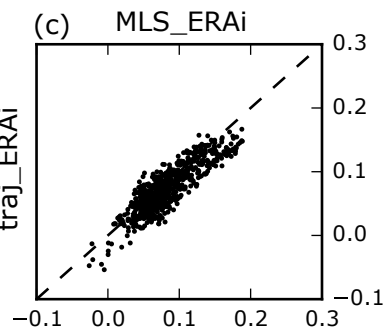

(f) MLS_MER2

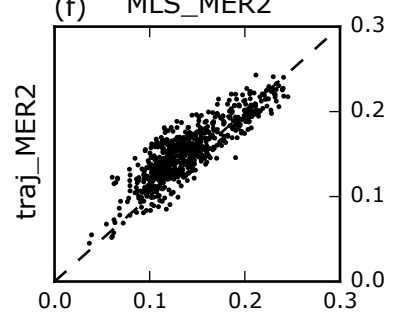

Figure 3. Same as Fig. 2 but for coefficients of the QBO regressor.

where. The trajectory model, which does not include this process, simulates a smaller increase in water vapor, leading to smaller $\Delta T$ coefficients (Fig. $4 \mathrm{c}$ and f).

In support of this, in Fig. 6a, we show that the tropical average convective cloud occurrence frequency anomalies in the lower stratosphere increase with $\Delta T$. This is consistent with the hypothesis that, as $\Delta T$ increases, we should also see an increase in evaporation of cloud ice.

\subsection{Tests with a chemistry-climate model}

To gain additional confidence in our hypothesis that evaporation of convective ice plays a role in the TTL water budget, we perform a parallel analysis with the GEOSCCM, a model where evaporation of convective ice is known to add water to the TTL (Dessler et al., 2016). To do this, we run a regression on the GEOSCCM $100 \mathrm{hPa}$ water vapor fields as well as on water vapor simulated by a trajectory model driven by the GEOSCCM meteorology.

Figure $2 \mathrm{~g}$ and $\mathrm{h}$ show the spatial distributions of the BDC coefficients from the GEOSCCM and the corresponding trajectory model. This comparison is analogous to the comparison of the regressions on the MLS data and trajectory models driven by reanalyses. The coefficients are similar to each other and to the MLS regressions, suggesting that the GEOSCCM is accurately simulating the impact of BDC changes on TTL water vapor. The influence of the QBO in the version of the GEOSCCM analyzed here does not extend into the TTL, so we have not included a QBO term in the regression and there are consequently no GEOSCCM QBO coefficients in Fig. 3.

Before we discuss the $\Delta T$ coefficients, it is worth pointing out that the GEOSCCM has realistic El Niño-Southern Oscillation (ENSO) variability in TTL temperatures and con- vective ice. Figure $5 \mathrm{c}$ and $\mathrm{d}$ show that the monthly convective cloud ice water content (IWC) anomalies at $118 \mathrm{hPa}$ and cold anomalies at $100 \mathrm{hPa}$ in the GEOSCCM shift eastward as $\Delta T$ warms from a cold phase (Fig. 5c) to a warm phase (Fig. 5d), just as they did in observations (Fig. 5a and b).

The $\Delta T$ coefficient fields from the GEOSCCM and associated trajectory model regressions (Fig. $4 \mathrm{~g}$ and $\mathrm{h}$ ) show the same structural differences as do the $\Delta T$ coefficients from the MLS and accompanying trajectory model regressions - that the $\Delta T$ coefficient is larger in the GEOSCCM regression than in the trajectory model regression - as in the observations; the tropical average $\Delta T$ coefficients from the GEOSCCM and trajectory model are significantly different at the $85 \%$ confidence level.

In the last section, we hypothesized that this difference in the coefficients was due to evaporation of convective ice in the MLS data, a process not included in the trajectory model. To directly test this hypothesis in the GEOSCCM, we run a second version of the trajectory model that includes the evaporation of convective ice from GEOSCCM, referred to hereafter as traj_CCM_ice. To do this, we use the 6-hourly threedimensional convective cloud IWC field from GEOSCCM and linearly interpolate it to each parcel's position at every time step. We then assume instantaneous and complete evaporation of this ice into the parcel by adding the IWC to the parcel's water vapor, although we do not let parcels' water vapor exceed $100 \%$ relative humidity with respect to ice. This is the same procedure used to simulate convective ice evaporation by Dessler et al. (2016).

We then run the regression on the traj_CCM_ice's water vapor field. The scatter plot of GEOSCCM vs. traj_CCM_ice BDC coefficients (Fig. 2k) shows larger scatter than the comparison without ice (Fig. 2i). The increase in scatter is 


\section{$\Delta \mathrm{T}$ coefficients [ppmv $\mathrm{K}^{-1}$ ]}
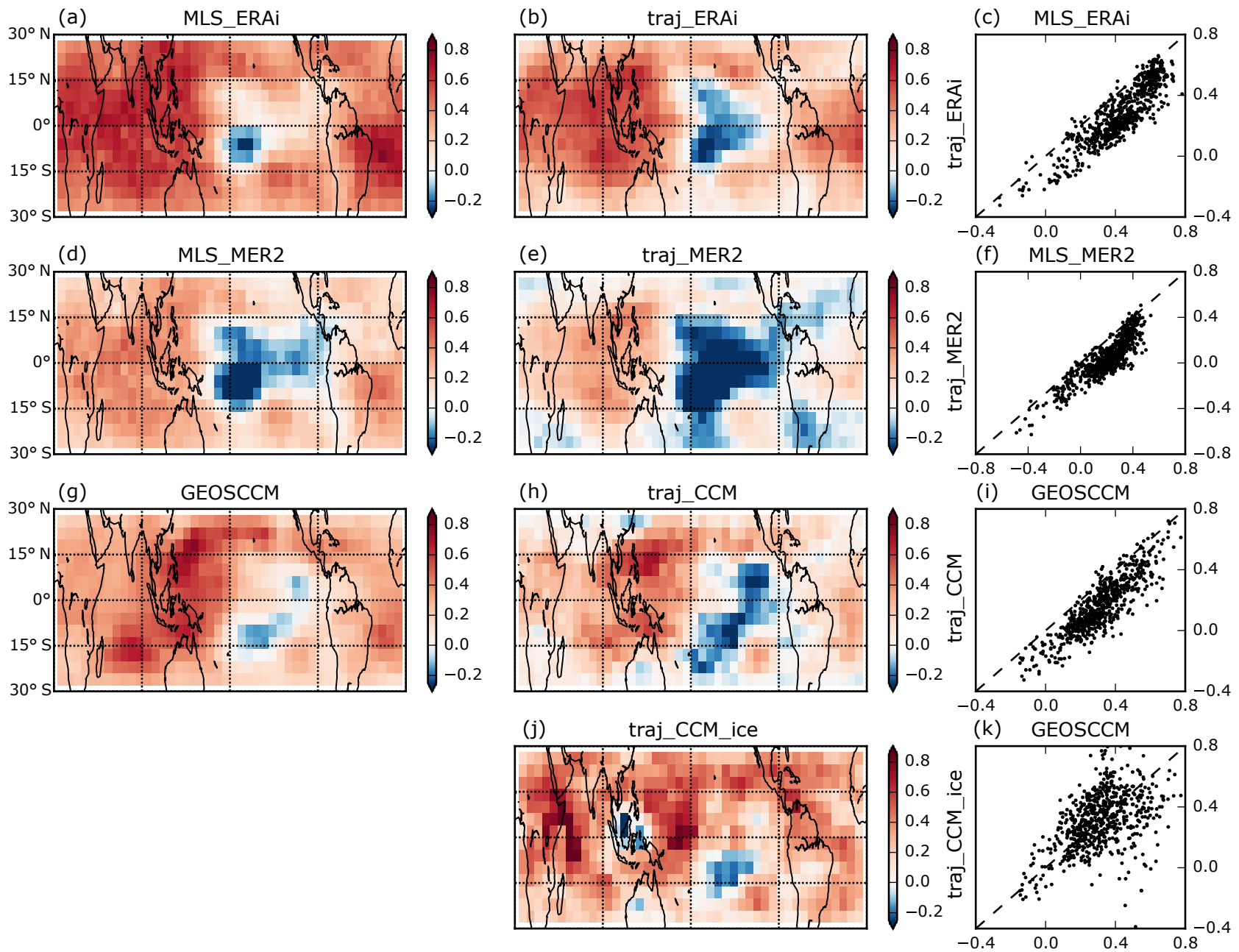

Figure 4. Same as Fig. 2 but for the coefficient of the $\Delta T$ regressor.

likely the result of the crudeness of our microphysical assumptions, particularly the assumption that convective ice evaporates instantaneously. However, the comparison between the tropical average GEOSCCM BDC coefficient, $-6.2 \mathrm{ppmv}\left(\mathrm{K} \mathrm{day}^{-1}\right)^{-1}$, and those from the trajectory models, -5.8 and $-6.9 \mathrm{ppmv}\left(\mathrm{K} \mathrm{day}^{-1}\right)^{-1}$ without and with convective ice evaporation, respectively, is similar.

The scatter plot of GEOSCCM vs. traj_CCM_ice $\Delta T$ coefficients (Fig. 4k) similarly shows larger scatter than the comparison without ice (Fig. 4i). Adding ice does, however, increase the average $\Delta T$ coefficient (seen by comparing Fig. $4 \mathrm{i}$ to $\mathrm{k}$ ), from 0.16 to $0.32 \mathrm{ppmv} \mathrm{K}^{-1}$, bringing the trajectory model into closer agreement with the GEOSCCM, which has a corresponding value of $0.31 \mathrm{ppmv} \mathrm{K}^{-1}$. There are also some interesting changes in the spatial pattern of the traj_CCM_ice (Fig. 4j). For example, negative $\Delta T$ coefficients appear in the TWP and Indonesia in the traj_CCM_ice regression; the cause of this is unknown but also is likely linked to the trajectory model's ice evaporation assumption.

We showed in the previous section that the convective cloud occurrence frequency in the TTL increased as $\Delta T$ increased (Fig. 6a) and we also see that the GEOSCCM simulates a similar correlation between convective cloud IWC and $\Delta T$ (Fig. 6b). While these are not exactly the same quantity, they show a consistency that provides confidence that the behavior of the model is realistic.

Finally, to quantify convective ice evaporation, we calculate the evaporation rate of convective ice at $100 \mathrm{hPa}$ in the trajectory model. To do this, we save the amount of water added to each parcel by ice evaporation in every time step. We then bin and average the amount evaporated to come up with the distribution of the amount evaporated per day. Note that much of this water added will be lost in subsequent dehydration events, so this does not represent net water added to the stratosphere. 

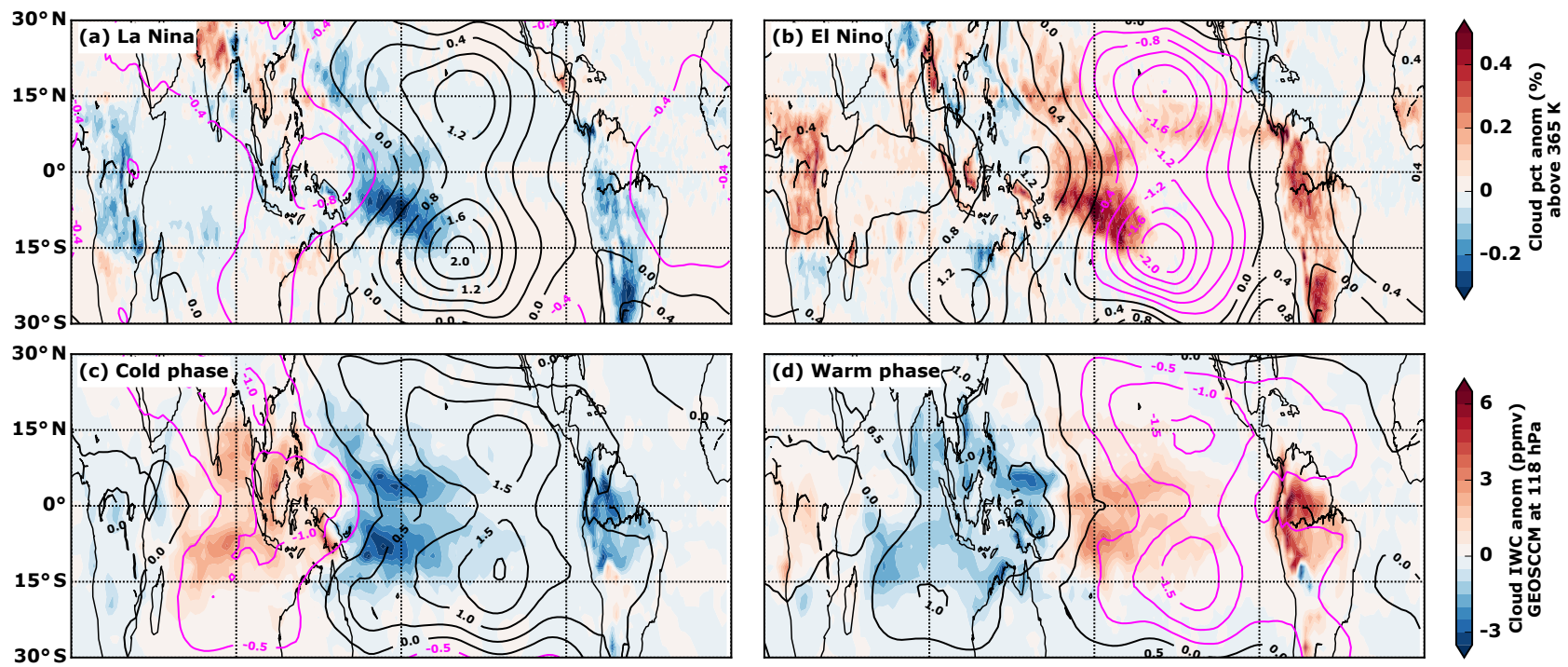

Figure 5. Averaged monthly cloud occurrence frequency anomalies above $365 \mathrm{~K}$ during (a) La Niña and (b) El Niño months from 2005 to 2016; also shown as contours are temperature anomalies at $100 \mathrm{hPa}$. La Niña and El Niño months are based on the NOAA Oceanic Niño Index $(\mathrm{ONI})$ in the Niño3.4 region $\left(5^{\circ} \mathrm{S}\right.$ to $5^{\circ} \mathrm{N} ; 170$ to $\left.120^{\circ} \mathrm{W}\right)$. Averaged monthly GEOSCCM convective cloud ice water content (IWC) anomalies (ppmv) at $118 \mathrm{hPa}$ during (c) cold and (d) warm GEOSCCM phases from model years 2005 to 2016 with averaged temperature anomalies at $100 \mathrm{hPa}$ are shown as contours. The cold and warm phases are defined to be GEOSCCM surface temperature anomalies (departures from the mean annual cycle) of at least -0.5 and $+0.5 \mathrm{~K}$, respectively, in the Niño3.4 region (same as ONI).
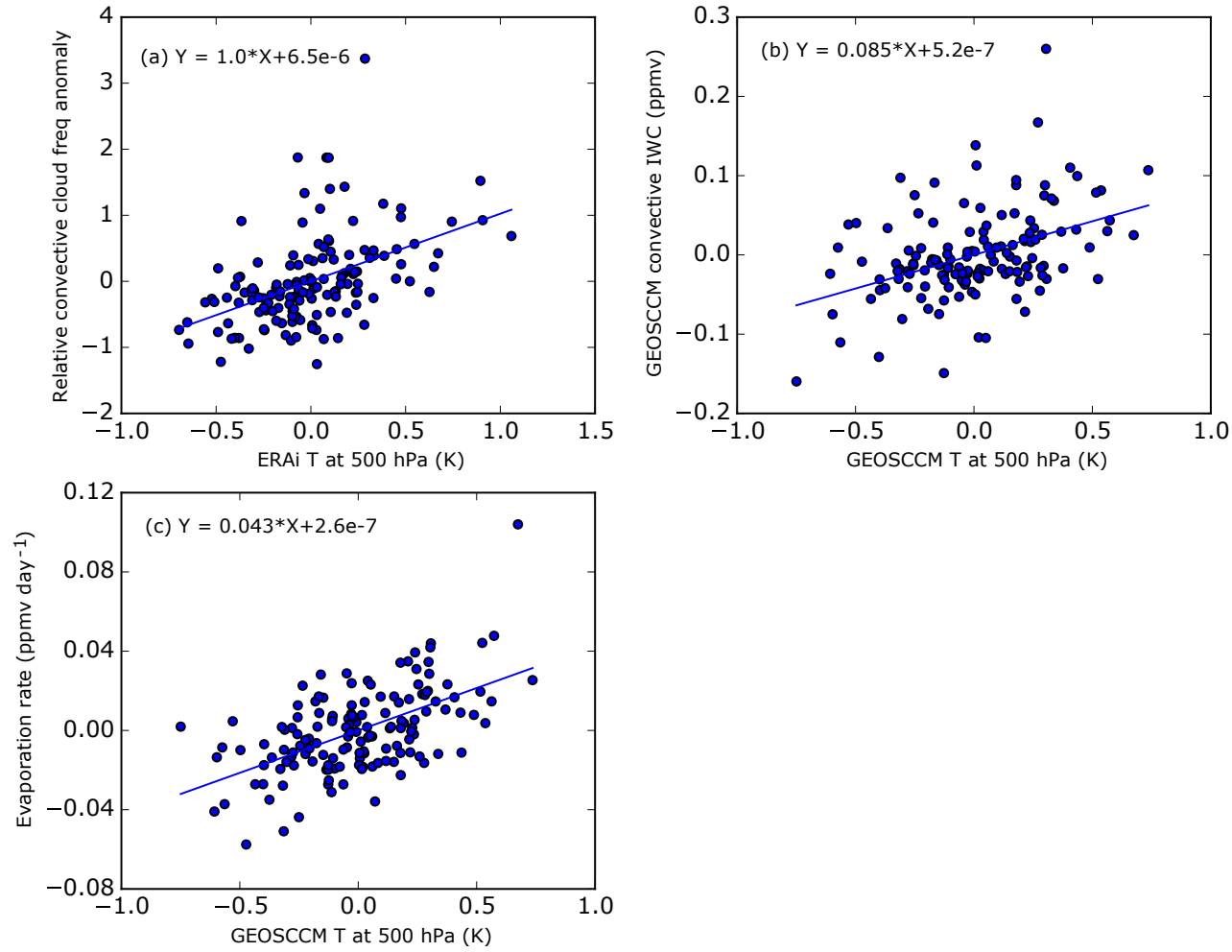

Figure 6. (a) Scatter plot of observed convective cloud occurrence frequency anomalies at $390 \mathrm{~K}$ vs. $500 \mathrm{hPa} \Delta T$ from ERAi. Cloud frequency is expressed as the percent change relative to the average cloud frequency at this level $\left(1.2 \times 10^{-6}\right.$ in tropics). (b) Scatter plot of convective IWC anomalies at $100 \mathrm{hPa}$ vs. $\Delta T$ from GEOSCCM. (c) Scatter plot of GEOSCCM convective cloud evaporation rate anomalies at $100 \mathrm{hPa}$ vs. $\Delta T$. All the data are monthly and tropical averaged from $30^{\circ} \mathrm{S}$ to $30^{\circ} \mathrm{N}$. The straight lines are least-squares fits to the data. 


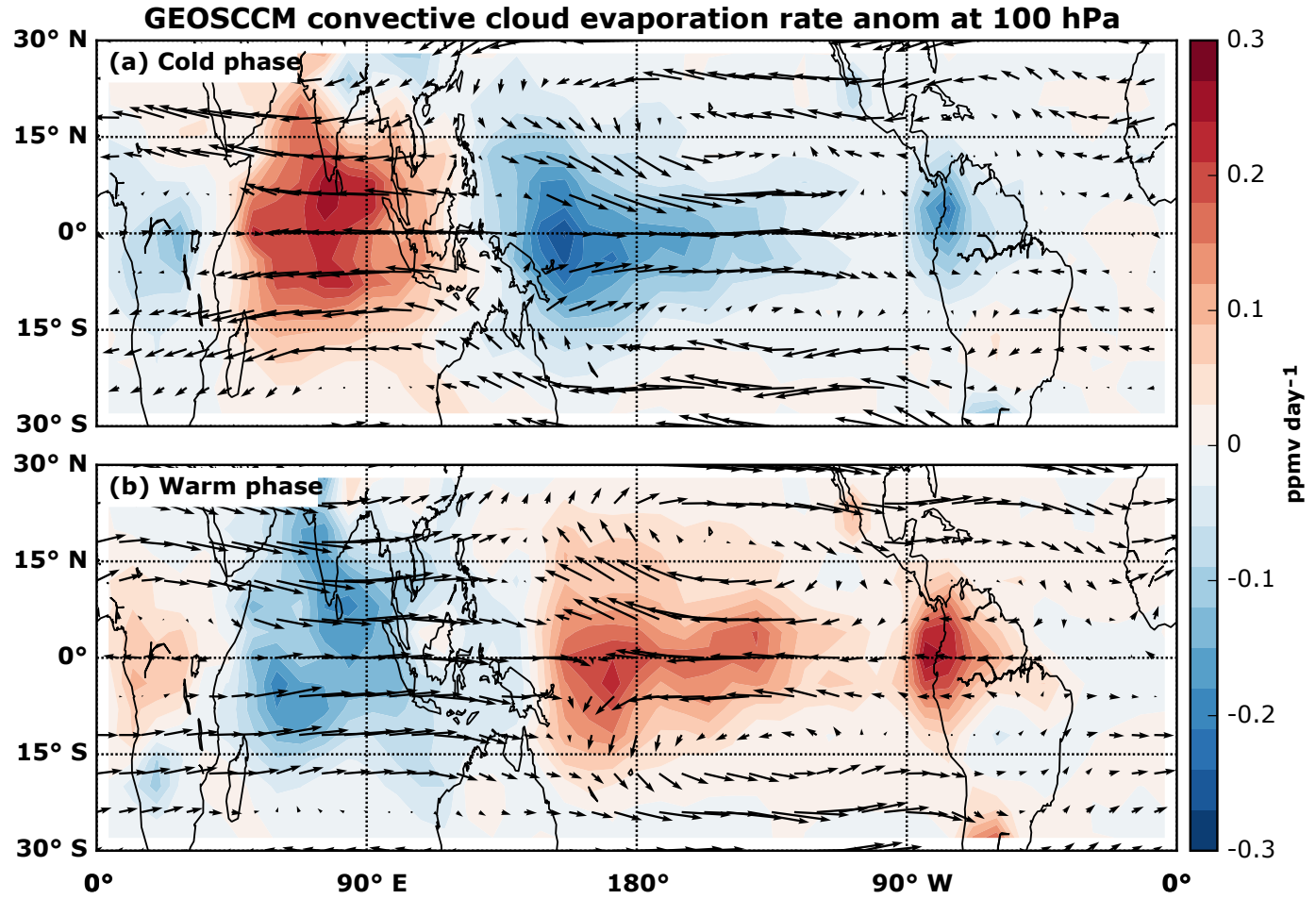

Figure 7. Averaged monthly GEOSCCM convective ice evaporation rate anomalies at $100 \mathrm{hPa}$ during (a) cold and (b) warm GEOSCCM phases from 2005 to 2016. Also shown are averaged horizontal wind anomaly vectors at $100 \mathrm{hPa}$.

Figure $6 c$ shows that the tropical average evaporation rate of convective ice also increases with $\Delta T$, which provides further evidence that the difference in $\Delta T$ coefficients between the GEOSCCM and the trajectory model is due to evaporation of convective ice. Figure 7 shows the distribution of the monthly averaged evaporation rate during ENSO-like cold and warm phases in the GEOSCCM. We see that, as $\Delta T$ increases and we transition from a cold to warm phase of variability, the location of ice evaporation shifts from the TWP and Indian Ocean to the CEP. This is consistent with the analysis of Avery et al. (2017).

\section{Conclusions}

Previous work has shown that TTL water vapor variability is mainly controlled by TTL temperature variability (Mote et al., 1996; Holton and Gettelman, 2001; Fueglistaler et al., 2009). In particular, variations in the BDC and QBO play key roles (Fueglistaler and Haynes, 2005; Geller et al., 2002; Liang et al., 2011; Liess and Geller, 2012; Calvo et al., 2010; Randel et al., 2006; Dessler et al., 2013, 2014; Tao et al., 2015). It has also been suggested by many previous investigators that evaporation of convective ice may contribute water vapor to the TTL (Khaykin et al., 2009; Hassim and Lane, 2010; Carminati et al., 2014; Frey et al., 2015; Virts and Houze, 2015; Schoeberl and Dessler, 2011; Schoeberl et al.,
2014; Ueyama et al., 2014, 2015; Dessler et al., 2016; Avery et al., 2017). In this paper, we analyze the spatial distribution of TTL water vapor and conclude that, indeed, convective ice evaporation makes a small contribution to the interannual variability over the MLS period.

To do that, we use a linear regression model on TTL water vapor at individual grid points over the tropics to decompose the spatial distribution of TTL water vapor variability into contributions from changes in the BDC, QBO, and tropospheric temperature $(\Delta T)$. We run this linear regression model on MLS observations of TTL water vapor anomalies and on water vapor anomalies simulated by a trajectory model that only includes the effects of TTL temperatures on water vapor.

The spatial patterns and magnitudes of the BDC and QBO coefficients agree well between MLS observations and associated trajectory model simulations. This confirms that these processes affect TTL water vapor mainly by changing TTL temperatures (Randel et al., 2000, 2006; Geller et al., 2002; Dhomse et al., 2008; Liang et al., 2011; Davis et al., 2013; Dessler et al., 2013, 2014).

The spatial distribution of $\Delta T$ coefficients has an obvious dipole structure associated with the ENSO (Konopka et al., 2016): negative values in the CEP, where temperatures decrease as the troposphere warms, and positive values in the TWP, where the opposite occurs. 
We also find that $\Delta T$ coefficients from the MLS observations are larger throughout the tropics than in the trajectory model simulations. We hypothesize that increases in convection as $\Delta T$ increases lead to increases in evaporation of convective ice in the TTL. This increases the $\Delta T$ coefficient in the MLS analysis, but not in the trajectory model, which does not have convective ice evaporation in it. We see support for this in the observations of increased convective cloud occurrence frequency in the TTL as $\Delta T$ increases. This result is also in agreement with the case study in Avery et al. (2017) as well as the model analysis in Schoeberl and Dessler (2011), Schoeberl et al. (2014), and Ueyama et al. (2014, 2015).

To gain additional confidence in our hypothesis that evaporation of convective ice is responsible for the difference in $\Delta T$ coefficients, we test the methodology in a parallel analysis with the GEOSCCM, a chemistry-climate model where evaporation of convective ice is known to add water to the TTL (Dessler et al., 2016). We find that the results of this analysis show the same difference - that the $\Delta T$ coefficients from the regression of the GEOSCCM's water vapor field are larger than the coefficients from a trajectory model driven by GEOSCCM meteorology.

We confirm this is due to evaporation of convective ice by running a second version of the trajectory model, which includes convective ice evaporation. We find that the $\Delta T$ coefficient from the regression of this version of the trajectory model is in agreement with that from the GEOSCCM regression.

Putting all of these together, we conclude that variability in the evaporation of convective ice plays a role in water vapor variability in the TTL. Our work should not be taken as opposing previous research (Randel et al., 2006; Schiller et al., 2009; Wright et al., 2011; Randel and Jensen, 2013) that concluded that most of the variability in TTL water vapor over the last few decades is due to TTL temperatures. We concur that the impact of convective ice only is a minor contributor to TTL water vapor variability over the period spanned by the MLS data. But the GEOSCCM, which does an excellent job simulating TTL water vapor over the comparable period, suggests that convective ice may play a much larger role in long-term trends of TTL and stratospheric water vapor (Dessler et al., 2016), so more research on this phenomenon is clearly warranted.

Code and data availability. The water vapor observations from MLS are available from https://mls.jpl.nasa.gov/. The observed convective cloud top data are available from https://bocachica.arc.nasa. gov/ lpfister/cloudtop/ (Pfister et al., 2017). The monthly water vapor data from GEOSCCM and trajectory model simulations are available from https://doi.org/10.5281/zenodo.1205759 (Ye et al., 2018). The codes for this paper are available on GitHub at https: //github.com/yehao2013/Ye-et-al-2018 (Ye, 2018).
Competing interests. The authors declare that they have no conflict of interest.

Acknowledgements. We thank Mark Schoeberl for his insights into this problem. This work was supported by NASA grants NNX14AF15G and 80NSSC18K0134 to Texas A\&M University. We would like to thank Luke Oman and Anne Douglass for providing the GEOSCCM simulation used in this study. The GEOSCCM modeling effort is supported by the NASA MAP program, and the high-performance computing resources were provided by the NASA Center for Climate Simulation (NCCS).

Edited by: Eric Jensen

Reviewed by: two anonymous referees

\section{References}

Anderson, J. G., Wilmouth, D. M., Smith, J. B., and Sayres, D. S.: UV dosage levels in summer: Increased risk of ozone loss from convectively injected water vapor, Science, 337, 835-839, 2012.

Avery, M. A., Davis, S. M., Rosenlof, K. H., Ye, H., and Dessler, A. E.: Large anomalies in lower stratospheric water vapour and ice during the 2015-2016 El Niño, Nat. Geosci., 10, 405-409, 2017.

Bacmeister, J. T., Suarez, M. J., and Robertson, F. R.: Rain reevaporation, boundary layer-convection interactions, and Pacific rainfall patterns in an AGCM, J. Atmos. Sci., 63, 3383-3403, 2006.

Barahona, D., Molod, A., Bacmeister, J., Nenes, A., Gettelman, A., Morrison, H., Phillips, V., and Eichmann, A.: Development of two-moment cloud microphysics for liquid and ice within the NASA Goddard Earth Observing System Model (GEOS-5), Geosci. Model Dev., 7, 1733-1766, https://doi.org/10.5194/gmd7-1733-2014, 2014.

Bergman, J. W., Jensen, E. J., Pfister, L., and Yang, Q.: Seasonal differences of vertical-transport efficiency in the tropical tropopause layer: On the interplay between tropical deep convection, large-scale vertical ascent, and horizontal circulations, J. Geophys. Res.-Atmos., 117, D05302, https://doi.org/10.1029/2011JD016992, 2012.

Bosilovich, M., Lucchesi, R., and Suarez, M.: MERRA-2: File specification, GMAO Office Note No. 9 (Version 1.1), Tech. Rep. Version 1.1, Global Modeling and Assimilation Office, 2016.

Bowman, K. P.: Large-scale isentropic mixing properties of the Antarctic polar vortex from analyzed winds, J. Geophys. Res.Atmos., 98, 23013-23027, 1993.

Bowman, K. P. and Carrie, G. D.: The mean-meridional transport circulation of the troposphere in an idealized GCM, J. Atmos. Sci., 59, 1502-1514, 2002.

Calvo, N., Garcia, R., Randel, W., and Marsh, D.: Dynamical mechanism for the increase in tropical upwelling in the lowermost tropical stratosphere during warm ENSO events, J. Atmos. Sci., 67, 2331-2340, 2010.

Carminati, F., Ricaud, P., Pommereau, J.-P., Rivière, E., Khaykin, S., Attié, J.-L., and Warner, J.: Impact of tropical land convection on the water vapour budget in the tropical tropopause layer, Atmos. Chem. Phys., 14, 6195-6211, https://doi.org/10.5194/acp14-6195-2014, 2014. 
Corti, T., Luo, B. P., De Reus, M., Brunner, D., Cairo, F., Mahoney, M. J., Martucci, G., Matthey, R., Mitev, V., Dos Santos, F. H., Schiller, C., Shur, G., Sitnikov, N. M., Spelten, N., Vössing, H. J., Borrmann, S., and Peter, T.: Unprecedented evidence for deep convection hydrating the tropical stratosphere, Geophys. Res. Lett., 35, L10810, https://doi.org/10.1029/2008GL033641, 2008.

Davis, S. M., Liang, C. K., and Rosenlof, K. H.: Interannual variability of tropical tropopause layer clouds, Geophys. Res. Lett., 40, 2862-2866, 2013.

Dee, D. P., Uppala, S. M., Simmons, A. J., Berrisford, P., Poli, P., Kobayashi, S., Andrae, U., Balmaseda, M. A., Balsamo, G., Bauer, P., Bechtold, P., Beljaars, A. C. M., van de Berg, L., Bidlot, J., Bormann, N., Delsol, C., Dragani, R., Fuentes, M., Geer, A. J., Haimberger, L., Healy, S. B., Hersbach, H., Hólm, E. V., Isaksen, L., Kållberg, P., Köhler, M., Matricardi, M., McNally, A. P., Monge-Sanz, B. M., Morcrette, J.-J., Park, B.-K., Peubey, C., de Rosnay, P., Tavolato, C., Thépaut, J.-N., and Vitart, F.: The ERA-Interim reanalysis: Configuration and performance of the data assimilation system, Q. J. Roy. Meteor. Soc., 137, 553-597, 2011.

Dessler, A. and Sherwood, S.: Effect of convection on the summertime extratropical lower stratosphere, J. Geophys. Res.-Atmos., 109, D23301, https://doi.org/10.1029/2004JD005209, 2004.

Dessler, A., Hanisco, T., and Fueglistaler, S.: Effects of convective ice lofting on $\mathrm{H}_{2} \mathrm{O}$ and $\mathrm{HDO}$ in the tropical tropopause layer, J. Geophys. Res.-Atmos., 112, D18309, https://doi.org/10.1029/2007JD008609, 2007.

Dessler, A., Schoeberl, M., Wang, T., Davis, S., and Rosenlof, K.: Stratospheric water vapor feedback, P. Natl. Acad. Sci. USA, 110, 18087-18091, 2013.

Dessler, A., Schoeberl, M., Wang, T., Davis, S., Rosenlof, K., and Vernier, J.-P.: Variations of stratospheric water vapor over the past three decades, J. Geophys. Res.-Atmos., 119, 12588-12598, https://doi.org/10.1002/2014JD021712, 2014.

Dessler, A., Ye, H., Wang, T., Schoeberl, M., Oman, L., Douglass, A., Butler, A., Rosenlof, K., Davis, S., and Portmann, R.: Transport of ice into the stratosphere and the humidification of the stratosphere over the 21 st century, Geophys. Res. Lett., 43, 2323-2329, https://doi.org/10.1002/2016GL067991, 2016.

Dhomse, S., Weber, M., and Burrows, J.: The relationship between tropospheric wave forcing and tropical lower stratospheric water vapor, Atmos. Chem. Phys., 8, 471-480, https://doi.org/10.5194/acp-8-471-2008, 2008.

Dvortsov, V. L. and Solomon, S.: Response of the stratospheric temperatures and ozone to past and future increases in stratospheric humidity, J. Geophys. Res.-Atmos., 106, 7505-7514, 2001.

Forster, P. M. de F. and Shine, K. P.: Stratospheric water vapor changes as a possible contributor to observed stratospheric cooling, Geophys. Res. Lett., 26, 3309-3312, 1999.

Frey, W., Schofield, R., Hoor, P., Kunkel, D., Ravegnani, F., Ulanovsky, A., Viciani, S., D'Amato, F., and Lane, T. P.: The impact of overshooting deep convection on local transport and mixing in the tropical upper troposphere/lower stratosphere (UTLS), Atmos. Chem. Phys., 15, 6467-6486, https://doi.org/10.5194/acp-15-6467-2015, 2015.

Fueglistaler, S. and Haynes, P.: Control of interannual and longerterm variability of stratospheric water vapor, J. Geophys. Res.-
Atmos., 110, D24108, https://doi.org/10.1029/2005JD006019, 2005.

Fueglistaler, S., Dessler, A., Dunkerton, T., Folkins, I., Fu, Q., and Mote, P. W.: Tropical tropopause layer, Rev. Geophys., 47, RG1004, https://doi.org/10.1029/2008RG000267, 2009.

Fueglistaler, S., Abalos, M., Flannaghan, T. J., Lin, P., and Randel, W. J.: Variability and trends in dynamical forcing of tropical lower stratospheric temperatures, Atmos. Chem. Phys., 14, 13439-13453, https://doi.org/10.5194/acp-14-13439-2014, 2014.

Geller, M. A., Zhou, X., and Zhang, M.: Simulations of the interannual variability of stratospheric water vapor, J. Atmos. Sci., 59, 1076-1085, 2002.

Gettelman, A., Liu, X., Ghan, S. J., Morrison, H., Park, S., Conley, A., Klein, S. A., Boyle, J., Mitchell, D., and Li, J.-L.: Global simulations of ice nucleation and ice supersaturation with an improved cloud scheme in the Community Atmosphere Model, J. Geophys. Res.-Atmos., 115, D18216, https://doi.org/10.1029/2009JD013797, 2010.

Gilford, D. M., Solomon, S., and Portmann, R. W.: Radiative impacts of the 2011 abrupt drops in water vapor and ozone in the tropical tropopause layer, J. Clim., 29, 595-612, 2016.

Giorgetta, M. A. and Bengtsson, L.: Potential role of the quasibiennial oscillation in the stratosphere-troposphere exchange as found in water vapor in general circulation model experiments, J. Geophys. Res.-Atmos., 104, 6003-6019, 1999.

Hassim, M. E. E. and Lane, T. P.: A model study on the influence of overshooting convection on TTL water vapour, Atmos. Chem. Phys., 10, 9833-9849, https://doi.org/10.5194/acp10-9833-2010, 2010.

Herman, R. L., Ray, E. A., Rosenlof, K. H., Bedka, K. M., Schwartz, M. J., Read, W. G., Troy, R. F., Chin, K., Christensen, L. E., Fu, D., Stachnik, R. A., Bui, T. P., and Dean-Day, J. M.: Enhanced stratospheric water vapor over the summertime continental United States and the role of overshooting convection, Atmos. Chem. Phys., 17, 6113-6124, https://doi.org/10.5194/acp17-6113-2017, 2017.

Holton, J. R. and Gettelman, A.: Horizontal transport and the dehydration of the stratosphere, Geophys. Res. Lett., 28, 2799-2802, 2001.

Hu, D., Tian, W., Guan, Z., Guo, Y., and Dhomse, S.: Longitudinal asymmetric trends of tropical cold-point tropopause temperature and their link to strengthened Walker circulation, J. Clim., 29, 7755-7771, 2016

Khaykin, S., Pommereau, J.-P., Korshunov, L., Yushkov, V., Nielsen, J., Larsen, N., Christensen, T., Garnier, A., Lukyanov, A., and Williams, E.: Hydration of the lower stratosphere by ice crystal geysers over land convective systems, Atmos. Chem. Phys., 9, 2275-2287, https://doi.org/10.5194/acp-9-2275-2009, 2009.

Konopka, P., Ploeger, F., Tao, M., and Riese, M.: Zonally resolved impact of ENSO on the stratospheric circulation and water vapor entry values, J. Geophys. Res.-Atmos., 121, 11486-11501, https://doi.org/10.1002/2015JD024698, 2016.

Lambert, A., Read, W. G., Livesey, N. J., Santee, M. L., Manney, G. L., Froidevaux, L., Wu, D. L., Schwartz, M. J., Pumphrey, H. C., Jimenez, C., Nedoluha, G. E., Cofield, R. E., Cuddy, D. T., Daffer, W. H., Drouin, B. J., Fuller, R. A., Jarnot, R. F., Knosp, B. W., Pickett, H. M., Perun, V. S., Snyder, W. V., Stek, P. C., 
Thurstans, R. P., Wagner, P. A., Waters, J. W., Jucks, K. W., Toon, G. C., Stachnik, R. A., Bernath, P. F., Boone, C. D., Walker, K. A., Urban, J., Murtagh, D., Elkins, J. W., and Atlas, E.: Validation of the Aura Microwave Limb Sounder middle atmosphere water vapor and nitrous oxide measurements, J. Geophys. Res.-Atmos., 112, D24S36, https://doi.org/10.1029/2007JD008724, 2007.

Lee, J., Yang, P., Dessler, A. E., Gao, B.-C., and Platnick, S.: Distribution and radiative forcing of tropical thin cirrus clouds, J. Atmos. Sci., 66, 3721-3731, 2009.

Liang, C., Eldering, A., Gettelman, A., Tian, B., Wong, S., Fetzer, E., and Liou, K.: Record of tropical interannual variability of temperature and water vapor from a combined AIRS-MLS data set, J. Geophys. Res.-Atmos., 116, D06103, https://doi.org/10.1029/2010JD014841, 2011.

Liess, S. and Geller, M. A.: On the relationship between QBO and distribution of tropical deep convection, J. Geophys. Res.Atmos., 117, D03108, https://doi.org/10.1029/2011JD016317, 2012

Livesey, N. J., Read, W. G., Wagner, P. A., Froidevaux, L., Lambert, A., Manney, G. L., Millán-Valle, L. F., Pumphrey, H. C., Santee, M. L., Schwartz, M. J., Wang, S., Fuller, R. A., Jarnot, R. F., Knosp, B. W., and Martinez, E.: Earth Observing System (EOS) Aura Microwave Limb Sounder (MLS), Version 4.2x Level 2 data quality and description document, Tech. Rep. JPL D-33509, Tech. Rep. version 4.2x-3.0, NASA Jet Propulsion Laboratory, 2017.

Molod, A., Takacs, L., Suarez, M., Bacmeister, J., Song, I.-S., and Eichmann, A.: The GEOS-5 atmospheric general circulation model: Mean climate and development from MERRA to Fortuna, Technical Report Series on Global Modeling and Data Assimilation Volume 28, NASA Goddard Space Flight Center, 2012.

Mote, P. W., Rosenlof, K. H., McIntyre, M. E., Carr, E. S., Gille, J. C., Holton, J. R., Kinnersley, J. S., Pumphrey, H. C., Russell, J. M., and Waters, J. W.: An atmospheric tape recorder: The imprint of tropical tropopause temperatures on stratospheric water vapor, J. Geophys. Res.-Atmos., 101, 3989-4006, 1996.

Murphy, D. and Koop, T.: Review of the vapour pressures of ice and supercooled water for atmospheric applications, Q. J. Roy. Meteor. Soc., 131, 1539-1565, 2005.

Oman, L. D. and Douglass, A. R.: Improvements in total column ozone in GEOSCCM and comparisons with a new ozonedepleting substances scenario, J. Geophys. Res.-Atmos., 119, 5613-5624, 2014.

Pawson, S., Stolarski, R. S., Douglass, A. R., Newman, P. A., Nielsen, J. E., Frith, S. M., and Gupta, M. L.: Goddard Earth Observing System chemistry-climate model simulations of stratospheric ozone-temperature coupling between 1950 and 2005, J. Geophys. Res.-Atmos., 113, D12103, https://doi.org/10.1029/2007JD009511, 2008.

Pfister, L., Selkirk, H. B., Jensen, E. J., Schoeberl, M. R., Toon, O. B., Browell, E. V., Grant, W. B., Gary, B., Mahoney, M. J., Bui, T. V., and Hintsa, E.: Aircraft observations of thin cirrus clouds near the tropical tropopause, J. Geophys. Res.-Atmos., 106, 9765-9786, 2001.

Pfister, L., Ueyama, R., Ryoo, J.-M., Hillyard, P. W., and Legg, M. J.: Convective cloud top height, available at: https://bocachica. arc.nasa.gov/ lpfister/cloudtop/, last access: 26 February 2017.
Plumb, R. A. and Bell, R. C.: A model of the quasi-biennial oscillation on an equatorial beta-plane, Q. J. Roy. Meteor. Soc., 108, 335-352, 1982.

Randel, W. J. and Jensen, E. J.: Physical processes in the tropical tropopause layer and their roles in a changing climate, Nat. Geosci., 6, 169-176, 2013.

Randel, W. J., Wu, F., and Gaffen, D. J.: Interannual variability of the tropical tropopause derived from radiosonde data and NCEP reanalyses, J. Geophys. Res.-Atmos., 105, 15-509, 2000.

Randel, W. J., Wu, F., Voemel, H., Nedoluha, G. E., and Forster, P.: Decreases in stratospheric water vapor after 2001: Links to changes in the tropical tropopause and the BrewerDobson circulation, J. Geophys. Res.-Atmos., 111, D12312, https://doi.org/10.1029/2005JD006744, 2006.

Read, W. G., Lambert, A., Bacmeister, J., Cofield, R. E., Christensen, L. E., Cuddy, D. T., Daffer, W. H., Drouin, B. J., Fetzer, E., Froidevaux, L., Fuller, R., Herman, R., Jarnot, R. F., Jiang, J. H., Jiang, Y. B., Kelly, K., Knosp, B. W., Kovalenko, L. J., Livesey, N. J., Liu, H.-C., Manney, G. L., Pickett, H. M., Pumphrey, H. C., Rosenlof, K. H., Sabounchi, X., Santee, M. L., Schwartz, M. J., Snyder, W. V., Stek, P. C., Su, H., Takacs, L. L., Thurstans, R. P., Vömel, H., Wagner, P. A., Waters, J. W., Webster, C. R., Weinstock, E. M., and Wu, D. L.: Aura Microwave Limb Sounder upper tropospheric and lower stratospheric $\mathrm{H}_{2} \mathrm{O}$ and relative humidity with respect to ice validation, J. Geophys. Res.-Atmos., 112, D24S35, https://doi.org/10.1029/2007JD008752, 2007.

Schiller, C., Grooß, J.-U., Konopka, P., Plöger, F., Silva dos Santos, F. H., and Spelten, N.: Hydration and dehydration at the tropical tropopause, Atmos. Chem. Phys., 9, 9647-9660, https://doi.org/10.5194/acp-9-9647-2009, 2009.

Schoeberl, M. R. and Dessler, A. E.: Dehydration of the stratosphere, Atmos. Chem. Phys., 11, 8433-8446, https://doi.org/10.5194/acp-11-8433-2011, 2011.

Schoeberl, M. R., Dessler, A. E., and Wang, T.: Simulation of stratospheric water vapor and trends using three reanalyses, Atmos. Chem. Phys., 12, 6475-6487, https://doi.org/10.5194/acp12-6475-2012, 2012.

Schoeberl, M. R., Dessler, A. E., and Wang, T.: Modeling upper tropospheric and lower stratospheric water vapor anomalies, Atmos. Chem. Phys., 13, 7783-7793, https://doi.org/10.5194/acp13-7783-2013, 2013.

Schoeberl, M. R., Dessler, A. E., Wang, T., Avery, M. A., and Jensen, E. J.: Cloud formation, convection, and stratospheric dehydration, Earth Space Sci., 1, 1-17, 2014.

Schwartz, M. J., Read, W. G., Santee, M. L., Livesey, N. J., Froidevaux, L., Lambert, A., and Manney, G. L.: Convectively injected water vapor in the North American summer lowermost stratosphere, Geophys. Res. Lett., 40, 2316-2321, 2013.

Sherwood, S. C. and Dessler, A. E.: On the control of stratospheric humidity, Geophys. Res. Lett., 27, 2513-2516, 2000.

Smalley, K. M., Dessler, A. E., Bekki, S., Deushi, M., Marchand, M., Morgenstern, O., Plummer, D. A., Shibata, K., Yamashita, Y., and Zeng, G.: Contribution of different processes to changes in tropical lower-stratospheric water vapor in chemistry-climate models, Atmos. Chem. Phys., 17, 8031-8044, https://doi.org/10.5194/acp-17-8031-2017, 2017.

Solomon, S., Rosenlof, K. H., Portmann, R. W., Daniel, J. S., Davis, S. M., Sanford, T. J., and Plattner, G.-K.: Contributions of strato- 
spheric water vapor to decadal changes in the rate of global warming, Science, 327, 1219-1223, 2010.

Stenke, A. and Grewe, V.: Simulation of stratospheric water vapor trends: impact on stratospheric ozone chemistry, Atmos. Chem. Phys., 5, 1257-1272, https://doi.org/10.5194/acp-5-1257-2005, 2005.

Sun, Y. and Huang, Y.: An examination of convective moistening of the lower stratosphere using satellite data, Earth Space Sci., 2, 320-330, 2015.

Tao, M., Konopka, P., Ploeger, F., Riese, M., Müller, R., and Volk, C. M.: Impact of stratospheric major warmings and the quasibiennial oscillation on the variability of stratospheric water vapor, Geophys. Res. Lett., 42, 4599-4607, 2015.

Ueyama, R., Jensen, E. J., Pfister, L., Diskin, G. S., Bui, T., and Dean-Day, J. M.: Dehydration in the tropical tropopause layer: A case study for model evaluation using aircraft observations, J. Geophys. Res.-Atmos., 119, 5299-5316, 2014.

Ueyama, R., Jensen, E. J., Pfister, L., and Kim, J.-E.: Dynamical, convective, and microphysical control on wintertime distributions of water vapor and clouds in the tropical tropopause layer, J. Geophys. Res.-Atmos., 120, 10483-10500, https://doi.org/10.1002/2015JD023318, 2015.

Virts, K. S. and Houze, Jr., R. A.: Clouds and water vapor in the tropical tropopause transition layer over mesoscale convective systems, J. Atmos. Sci., 72, 4739-4753, 2015.

Wang, T. and Dessler, A. E.: Analysis of cirrus in the tropical tropopause layer from CALIPSO and MLS data: A water perspective, J. Geophys. Res.-Atmos., 117, D04211, https://doi.org/10.1029/2011JD016442, 2012.
Wang, T., Randel, W. J., Dessler, A. E., Schoeberl, M. R., and Kinnison, D. E.: Trajectory model simulations of ozone $\left(\mathrm{O}_{3}\right)$ and carbon monoxide (CO) in the lower stratosphere, Atmos. Chem. Phys., 14, 7135-7147, https://doi.org/10.5194/acp-147135-2014, 2014. .

Wang, W., Matthes, K., and Schmidt, T.: Quantifying contributions to the recent temperature variability in the tropical tropopause layer, Atmos. Chem. Phys., 15, 5815-5826, https://doi.org/10.5194/acp-15-5815-2015, 2015.

Wright, J., Fu, R., Fueglistaler, S., Liu, Y., and Zhang, Y.: The influence of summertime convection over Southeast Asia on water vapor in the tropical stratosphere, J. Geophys. Res.-Atmos., 116, D12302, https://doi.org/10.1029/2010JD015416, 2011.

Wright, J. S., Sobel, A. H., and Schmidt, G. A.: Influence of condensate evaporation on water vapor and its stable isotopes in a GCM, Geophys. Res. Lett., 36, L12804, https://doi.org/10.1029/2009GL038091, 2009.

Ye, H.: Programs for a recent paper Ye et al., 2018, available at: https://github.com/yehao2013/Ye-et-al-2018, last access: 26 March 2018.

Ye, H., Dessler, A., and Yu, W.: WV-TTL: water vapor mixing ratio from GEOSCCM and trajectory model simulations in tropical tropopause layer, available at: https://doi.org/10.5281/zenodo.1205759, 2018.

Yulaeva, E., Holton, J. R., and Wallace, J. M.: On the cause of the annual cycle in tropical lower-stratospheric temperatures, J. Atmos. Sci., 51, 169-174, 1994.

Zhou, C., Dessler, A., Zelinka, M., Yang, P., and Wang, T.: Cirrus feedback on interannual climate fluctuations, Geophys. Res. Lett., 41, 9166-9173, 2014. 